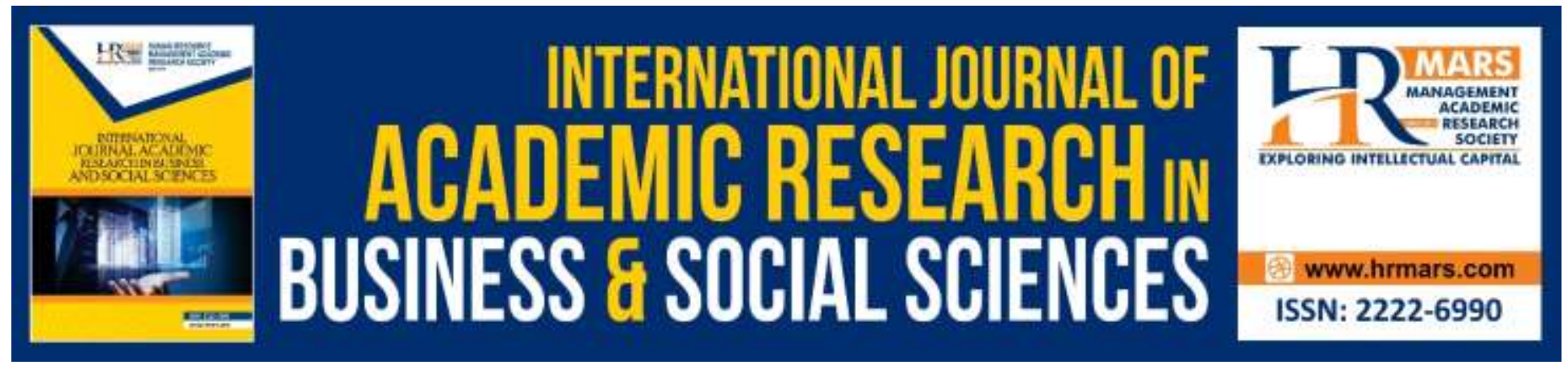

\title{
Effects of Emotional Labor on Job Satisfaction and Customer Satisfaction: An Empirical Study of Libyan Banks
}

Tarek Elganas, Reginald Sheppard

To Link this Article: http://dx.doi.org/10.6007/IJARBSS/v9-i11/6656 DOI:10.6007/IJARBSS/v9-i11/6656

Received: 10 September 2019, Revised: 15 October 2019, Accepted: 10 November 2019

Published Online: 30 November 2019

In-Text Citation: (Elganas, Sheppard, 2019)

To Cite this Article: Elganas, T., Sheppard, R. (2019). Effects of Emotional Labor on Job Satisfaction and Customer Satisfaction: An Empirical Study of Libyan Banks. International Journal of Academic Research in Business and Social Sciences, 9(11), 1261-1282.

Copyright: (c) 2019 The Author(s)

Published by Human Resource Management Academic Research Society (www.hrmars.com)

This article is published under the Creative Commons Attribution (CC BY 4.0) license. Anyone may reproduce, distribute, translate and create derivative works of this article (for both commercial and non-commercial purposes), subject to full attribution to the original publication and authors. The full terms of this license may be seen

at: http://creativecommons.org/licences/by/4.0/legalcode

Vol. 9, No. 11, 2019, Pg. 1261 - 1282

http://hrmars.com/index.php/pages/detail/IJARBSS

JOURNAL HOMEPAGE

Full Terms \& Conditions of access and use can be found at http://hrmars.com/index.php/pages/detail/publication-ethics 


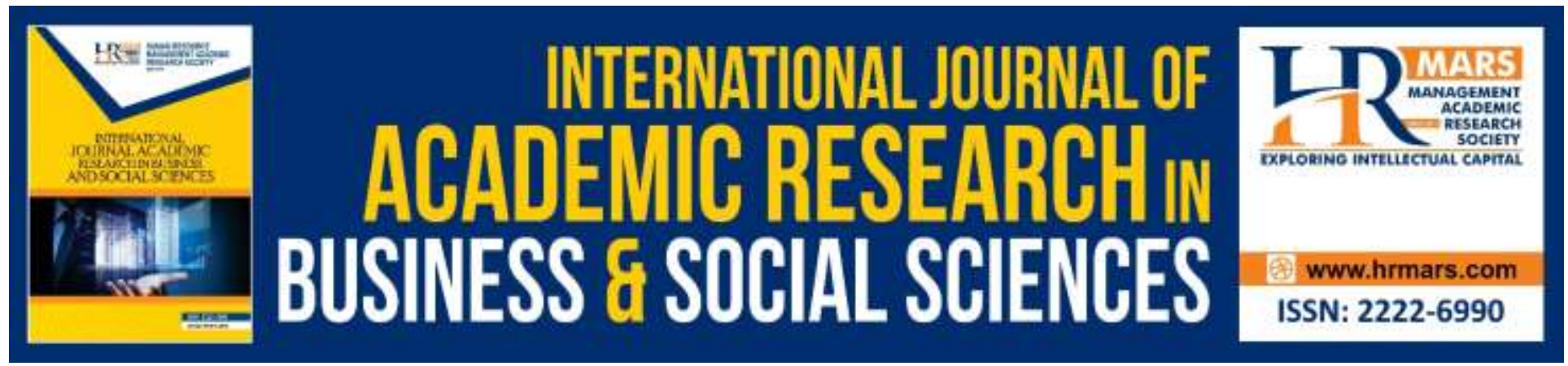

\title{
Effects of Emotional Labor on Job Satisfaction and Customer Satisfaction: An Empirical Study of Libyan Banks
}

\author{
Tarek Elganas, Reginald Sheppard \\ Department is interdisciplinary Study (IDST), University of New Brunswick \\ Email: tarek.elganas@unb.ca
}

\begin{abstract}
This study aims to examine the impact of surface acting and deep acting on customer satisfaction directly and with the mediation of job satisfaction. As well, we investigate the moderating effect of gender and emotional intelligence on emotional labor (surface acting and deep acting) and on job satisfaction. The data are collected through questionnaires from a sample of 364 banking professionals working in the Libyan banking industry, with data analysis being performed using SPSS software. Our research findings suggest significant relationships between surface acting and customer satisfaction, deep acting and customer satisfaction, surface acting and job satisfaction, deep acting and job satisfaction, and job satisfaction and customer satisfaction. The results also indicate that partial mediation of job satisfaction is also found in the relationship of emotional labor and customer satisfaction. Additionally, the moderating effect of gender and emotional intelligence was found to be significant on the relationship of deep acting and job satisfaction. The results are discussed with reference to previous studies. Study limitations and ideas for future research directions are also presented.
\end{abstract}

Keywords: Emotional Labor, Deep Acting, Surface Acting, Emotional Intelligence, Customer Satisfaction

\section{Introduction}

Some people assume that human resources and marketing are two separate principles, but the reality is that they are connected to each other in a variety of ways. The main objective of an organization is to earn a profit and increaser sales, but to increase sales, an organization must satisfy the customers' needs. Satisfaction of customers' needs starts with attaining and retaining talented employees. In short, to attract the target market and build profitability, companies must have employees who are both good at their jobs and enjoy their jobs. Therefore, in the present 
highly competitive era of globalism, it is critical for organizations to have a quality marketing staff to sell their product in the global marketplace.

Emotions are generated by the interaction of an individual with society. These interactions, and thus the emotions attached to them, can be positive or negative (Erdoğan, 2007; Ejike, 2018). Emotions are variables that change from person to person and situation to situation. They also depend on personal skills and attitudes (Bhave \& Glomb, 2016). Hochschild (1983) introduced the wider concept of emotional labor in her book The Management of Heart. According to the author, emotional labor involves applying social values and norms to individual behavior. Humphrey, Ashforth and Diefendorff (2015) defined emotional labor as an act or scene to express behavior in a workplace environment, claiming that emotional labor can be classified into four major dimensions: emotional labor, attention of emotional labor, emotional dissonance, and frequency of emotional labor.

More recently, Chapman and Evans (2016) presented a two-dimensional theory (deep acting and surface acting), defining deep acting as emotive effort and surface acting as emotive dissonance. In other words, surface acting is the difference between true emotions and fake emotions, or the expression of an emotion which is untrue and thus does not exist (Lee \& Chelladurai, 2018; Laban \& Deya, 2019). Deep acting, on the other hand, is the intensity of the expression of true emotions in the workplace (Chapman \& Evans, 2016). In this state, an employee attempts to comply existing emotions with required emotions. Deep acting allows the employee to focus on emotional expressions that are mandatory in the organization

The concept of emotional labor can be defined as a process that manages the emotions and feelings of an individual employee. As such, emotional labor helps to fulfill the need for the expression of emotions in the workplace. To achieve the goals of the organization, it is important for employees to maintain their emotions and express them while coordinating with co-workers, managers and customers. Individuals typically express their emotions during meetings, decisionmaking, and dealing with customers. Sometimes, employees feel emotions but fail to express them or they feel emotions too strongly and express them too strongly as well, resulting in problems at the workplace.

Emotions make up a large part of our lives. Whether directly or indirectly, the presence of emotions can be seen in reasoning and rationality, so disregarding emotions through lack of management, neglect to express them, or over-expression of them can come at a high cost to human beings. At the same time, feelings are as much a part of organizational life as they are of personal life, because organizations are made up of humans and humans are hard-wired to feel. Organizations can be a means by which people express, control, or deny their emotions; organization can also have the ability to modulate or intensify the emotions of individuals [1].

Management experts believe that organizations can achieve better performance by managing and organizing their employees' feelings. Hence, organizational emotion management is an 
important capability within organizations. This valuable resource can create a competitive advantage, and since emotional expression and management are based on natural capabilities, it would be difficult for competitors to imitate this capability. Emotions expressed within an organization are a basic factor of that organization and a very present reality for employees ( $\mathrm{Hu}$, \& King, 2017). These emotions may be direct or indirect, and used while making decisions or in any rational assessment. However, some organizations do not care about their employees' emotional expressions during their work hours and so ignore this critical factor. For this reason, employees may experience frustration, which then affects their job performance and job satisfaction.

Individuals cannot survive without feelings (Tepeci \& Pala, 2016). However, in many firms, the expression of feelings is not welcome, so individuals are forced to deny or heavily control their emotions. In some cases, individuals are expected to control their emotions during certain situations, especially in firms that equate emotional stability with good job performance (Tepeci \& Pala, 2016). Hence, emotion management within organizations can be for the benefit of the company or the benefit of individual employees, or it can work against both by stifling creativity and forcing the employees to work in a cold, controlled, emotionless environment.

A customer's responses are handled through surface acting (Abdelqader Alsakarneh et al., 2018). This requires an employee's original expression of emotions to surface without any variation in feeling (Grandey, 2003). Diefendorff et al. (2005) defined deep acting as a type of good faith and buyer cognition as a form of consumer satisfaction. In such an exchange, the customer effectively rewards the organization with the purchase of a goods and services (Kundu \& Datta, 2015). Similarly, an employee's job satisfaction can be measured through job contentedness. Job satisfaction includes aspects of the workplace such as organizational culture, the nature of the work, and relations with upper management (Chen et al., 2012).

Researchers also claim that emotional labor affects the organization's image as well as the job satisfaction of an employee (Diefendorff \& Richard, 2003; Grandey, 2003). Furthermore, emotional labor has an impact on employees' loyalty, quality of work, productivity, and even customer satisfaction (Hennig-Thurau et al., 2006; Groth et al., 2009). The study also shows a direct impact of deep action on customers' emotions, with surface acting and deep acting each having different impacts. Customer satisfaction and deep acting appear to have a positive relationship.

Previous research shows evidence that emotional labor increases stress in employees, leading to negative job satisfaction and overall negative organizational performance (Nixon et al., 2010). Numerous studies argue the negative impact of emotional labor on workers' outcomes, including job dissatisfaction, employee turnover, intention to quit, and bad organizational performance ( $\mathrm{LV}$ et al., 2012; Chau et al., 2008; Bartam et al., 2012). Bank employees are particularly stressed due to the nature of their job, as they are responsible for handling cash and cash-related transactions that are sensitive. Hence, in such cases, emotional labor can have a more adverse effect. 
However, emotional intelligence can be brought into the equation and help to check the relationship of emotional labor and job satisfaction.

Researchers based in Europe and North America have studied emotional labor very extensively. Their results show that workplace culture varies from organization to organization. Libyan organizations pay very little attention to emotional labor and as a result face a high rate of corruption, conflicts, and unrest within the organization (Guy, 2011). These problems create even more difficulties emotionally for employees. The current study expects to find a direct effect of deep and surface acting on customer satisfaction and an indirect influence through employee job satisfaction. The focus will be employees in the service industry, where customer interaction has more possibilities.

Moreover, the results of previous investigations indicate contradictory findings regarding the impact of emotional labor. There is also a lack of research using emotional labor and gender as moderators. Therefore, because of the strong support showing that emotional intelligence can impact job satisfaction, work/life balance and job performance (Lee \& Ok, 2012; Jordan \& Truth, 2011; Sony \& Mekoth, 2016), the present study examines the moderating role of emotional intelligence, which is the main contribution of the work to the research field.

\section{Aim of Study}

The current study is interdisciplinary in the sense that it involves concepts from psychology, human behavior, organizational psychology and organizational behavior. The main aim of the current study is to examine the relationship between emotional labor (i.e., surface acting and deep acting), job satisfaction and customer satisfaction. A secondary aim is to examine the extent to which job satisfaction mediates the relationship between emotional labor and customer satisfaction. Figure 1 below presents the hypothesized model for the relationships between emotional labor, job satisfaction, and customer satisfaction.

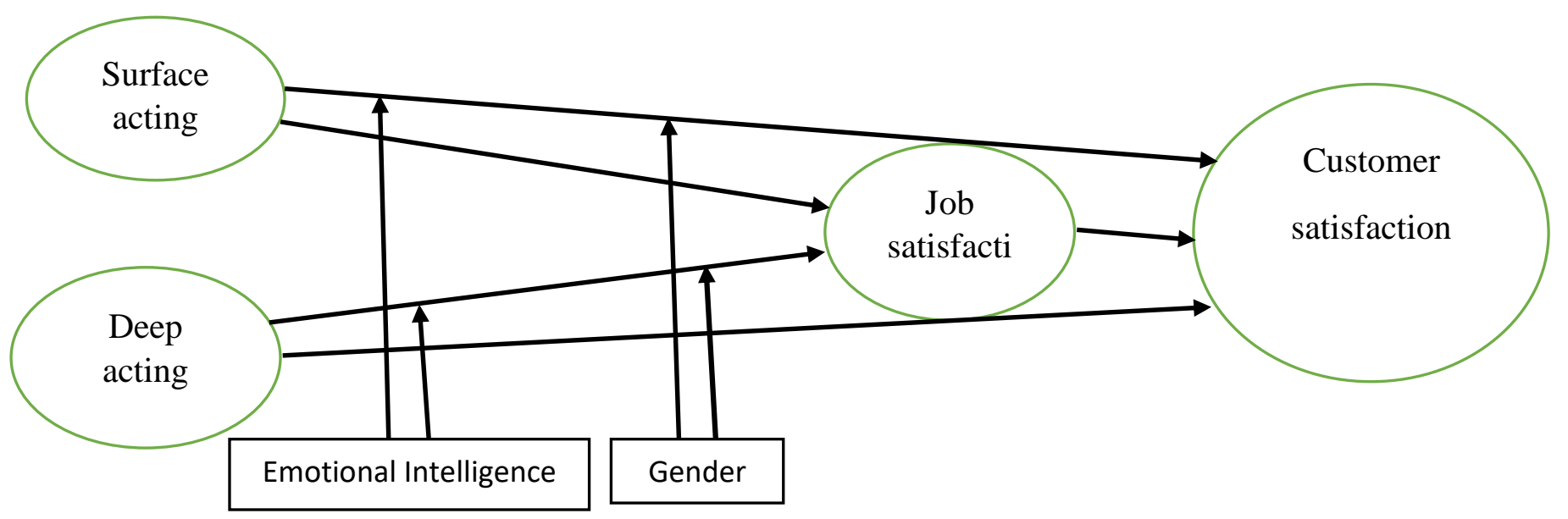

Figure 1: Model showing relationships between emotional labor, job satisfaction, and customer satisfaction. 


\section{Literature Review}

\section{Emotional Labor and Customer Satisfaction}

A number of studies have been conducted on how emotional labor improves employees' work environment by reducing job stress (Grandey, 2003), increasing job satisfaction (Diefendroff \& Richard, 2003), and enhancing performance delivery (Grandey, 2003). To date, however, very few studies have covered the effect of emotional labor on the consumer with regard to loyalty, quality of services, and customer satisfaction (Groth et al., 2009). Emotional labor can have a direct impact on a customer's emotional behavior through the quality services evaluation (Hennig-Thurau et al., 2006). Employees' emotional labor strategies are directly associated with customer satisfaction, and deep acting has significant relations with employees' service delivery to the customers (Groth et al., 2009).

Emotional labor impacts customers through employee performance in dealing with customers. This performance drives customer behavior, attitude and emotions towards specific satisfaction levels. Research shows that employees' emotions are required in order to develop loyalty among customers, as employees' emotions are reflected through increases in service quality and customer satisfaction (Delcourt et al., 2016; Alsakarneh et al., 2019). In fact, customers' informal mental and behavior analyses of employees meeting their desired expectations about products or services (including customer interaction) is a continuous process that can be encountered daily by employees as part of the job (Collier et al., 2018). If customers to obtain high quality services from employees, there is an increase in customer satisfaction level (Goodman, 2019).

Some studies suggest that employee attitude is highly influenced by employee behavior (Jung \& Yoon, 2015). Employee and customer interaction are a social factor that increases the ability of customers to analyze employee service, including their efforts towards satisfying their requirements (Tsai, 2001). Employees who are not satisfied with their job show direct (negative) impacts on the customers, leaving customers with poor quality services and an overall bad experience. In particular, employees who display "fake" or surface emotions strongly negatively influence customer behavior, emotions, attitude and satisfaction.

Surface actions include facial expressions that are observed by customers during employee/customer interactions and that directly indicate the behavior of the employee (Grandey, 2003). If, during an interaction with a customer, an employee's surface acting relays negative emotions in the form of anger while showing positive emotion in the form of smile, the customer will read these expressions as "fake" (Grandey, 2003). Such emotions indicate that the employee is operating in bad faith, disrespecting the customer and therefore having a negative impact on the customer. On the contrary, employees who use deep acting display different gestures when dealing with customers (Grandey, 2003). By using deep acting, employees act according to the organizational requirement to treat and deal with customers. Therefore, deep acting shows the employee acting in good faith, resulting in high levels of customer satisfaction (Diefendorff et al., 2005). 
In view of the discussed emotions, the following hypotheses are developed:

Hypothesis 1: Surface acting is negatively associated with customer satisfaction.

Hypothesis 2: Deep acting is positively associated with customer satisfaction.

\section{Emotional Labor and Job Satisfaction}

On the basis of the conservation of resources model, staff members are being encouraged to preserve their energy and develop resources in order to reduce the load of the work through effective means. However, emotional demands and performance requirements are not in balance with each other, so employees are not able to produce quality services and are thus not likely satisfied with their jobs (Pines, 2017). Surface acting includes employee motivation to exhibit seemingly natural emotions at work (Gabriel et al., 2016). Hence, surface acting is used by employees when they have a lack of interest in their job or are experiencing burnout; this is well supported by studies of employees working in Western countries (e.g., Beal et al., 2006) as well as those in China (e.g., Cheung \& Tang, 2009; 2010). Deep acting, on the other hand, exhibits an employee's psychological strength as represented through job satisfaction and sense of achievement towards personal objectives (Grandey, 2003). In the case of employees, fair work emotions suggest job satisfaction, better service quality towards customers, and low levels of stress at the workplace (Cheung \& Tang, 2010).

Hypothesis 3: Surface acting is negatively associated with job satisfaction.

Hypothesis 4: Deep acting is positively associated with job satisfaction.

\section{Employee Job Satisfaction and Customer Satisfaction}

In the current market, the relationship between employee job satisfaction and customer satisfaction is exhibiting direct and significant results. It is evident from the above-mentioned research that an employee's job satisfaction plays an important role in the satisfaction of customers; this has been observed in various industries beyond banking as well (Doucet, 2004). There are two different schools of thought that suggest that employee satisfaction is directly tied to customer satisfaction: these schools are emotional satisfaction and job benefits (Brown \& Lam, 2008). The relationship between employee satisfaction and customer satisfaction belongs to the theory of emotional contagion (Hatfield et al., 2018) and has been discussed in the literature (Barsade et al., 2018). From the studies, it is evident that customers are capable of assessing the behavior of employees who develop the service quality that can be offered to them (Hatfield et al., 2018). Organizational employees and customers have direct contact, which includes emotions and behavior combinations within quality of service. Once employees are satisfied with their job, their satisfaction will cause significant changes to their behavior. These changes will be noted by customers and they will become satisfied customers (Barsade et al., 2018).

Thus, employees who experience high levels of satisfaction with their job exhibit positive behavior towards their customers. In turn, the customers feel the positivity in the behavior of the employees, which increases their satisfaction level (Zablah et al., 2016). In view of the organizational benefit, employees who are highly satisfied are generally able to produce quality 
services, and this feature is transferred to customers through their performance and ability to satisfy the customers. It is also as relayed through their services that directly or indirectly impact organizational profitability (Sharma et al., 2016).

Organizational benefits are associated with employee job satisfaction, which in turn is associated with customer satisfaction as analyzed through service quality. Employees who are highly satisfied with their jobs tend to have high motivation to perform according to the organization's mandated standards, which then produces quality services and provides optimal value to the customer (Zablah et al., 2016). On the basis of this, the following hypothesis was developed: Hypothesis 5: Job satisfaction is positively associated with customer satisfaction.

\section{The Mediating Role of Job Satisfaction on the Emotional Labor and Customer Satisfaction Relationship}

Different studies in the area of emotional labor literature emphasize the relationship between emotional labor and employee job satisfaction (Diefendorff \& Richard, 2003; Grandey, 2000) or emotional labor and customer satisfaction (Hennig-Thurau et al., 2006; Groth et al., 2009), without looking at employee satisfaction in relation to customer satisfaction. It is argued here that service workers involved in emotional labor influence not only customer satisfaction but also job satisfaction at the workplace. Emotional contagion can be expressed as a two-concept model (Hatfield et al., 2018) and a service profit chain (Hogreve et al., 2017). A study on the relationship between emotional labor and customer satisfaction is actually a focus on job satisfaction, as this factor is the most essential mediating construct influencing employee emotional labor.

On the basis of the above, it is suggested that emotional regulation strategies are effective for both surface and deep acting, Surface acting and deep acting can significantly influence customer satisfaction in relation to employee satisfaction that directly influences customer satisfaction. Employees habitually exhibiting surface acting are likely to have low satisfaction levels with their job, which then leads to a lack of quality service and decreases the satisfaction level of the customers. Surface acting refers to the expression of obviously fake or superficial concern exhibited by employees towards customers, and it exerts a negative influence on customer satisfaction (Grandey, 2003). This is because the customers discern cognitive dissonance, where what is being expressed by the employee is not what is being relayed (Festinger, 1954). If employees are depressed and feel burdened by their workload, they "surface act" with customers, which creates a negative impact upon customers with regard to their satisfaction level.

On the other hand, research shows that deep acting by employees is highly effective and indicates that employees are satisfied with their job, which contributes positively towards overall employee satisfaction. Employees that are involved in surface acting reveal a lack of interest in the job and feel dissatisfied, whereas deep acting employees are more satisfied and thus offer better quality service to customers, increasing their satisfaction level (Adelman, 1995). Deep 
acting requires changes in internal behavior. Rather than becoming an emotional burnout (Arnold et al., 2015), deep acting encourages the attainment of personal objectives, selfconfidence, and a sense of personal responsibility (Brotheridge \& Lee, 2002; Brotheridge \& Grandey, 2002). Deep acting includes positivity in the mind of employees that reflects their job satisfaction and translates to high levels of customer satisfaction. On the basis of this discussion, the following hypotheses are developed:

Hypothesis 6: The relationship of surface acting and customer satisfaction is mediated by job satisfaction.

Hypothesis 7: The relationship of deep acting and customer satisfaction is mediated by job satisfaction.

\section{Moderating Role of Emotional Intelligence}

Emotional intelligence is a capability that helps individuals analyze their emotions and those of others as well (Wong \& Law, 2002). Individuals with high emotional intelligence are likely to be aware of their emotions and have a different perspective and aesthetic sense compared to others. They have the capability of formulizing their emotions in a self-constructive way and avoiding or mitigating psychological pressure. Individuals with high emotional intelligence are successful at displaying emotions that accord with organizational rules and standards and thus help customers gain satisfaction through their services. Those individuals with high emotional intelligence are considered skilled emotional laborers because they are likely to adapt to the felt and expressed behavior quickly (Geofroy \& Evans, 2017). Thus, deep acting is not only selfevident to them but is able to be successfully engaged by them in presenting their positive emotions to customers. Deep acting individuals require less effort in comparison to those with low emotional intelligence. Therefore, it is suggested that emotional intelligence is the main feature that enables employees to bring their performance of emotional labor through the effective use of emotional strategies.

In general, research shows that employees with high levels of emotional intelligence are very skilled at performing their emotions, feel less pressure, and get satisfaction from their job (Mohamad \& Jais, 2016). At the same time, surface acting can, for workers with high emotional intelligence, be a highly positive feature that helps these individuals to present positive emotions that impact directly and positively on customer satisfaction. This ability shows the level of satisfaction of employees as well. Overall, then, emotional intelligence decreases negativity among deep acting laborers and increases positivity among them to perform their required expectations.

Hypothesis 8: Emotional intelligence moderates the relationship of surface acting and job satisfaction.

Hypothesis 9: Emotional intelligence moderates the relationship of deep acting and job satisfaction. 


\section{Moderating Role of Gender}

Studies on emotional labor and gender have had significantly different results in the past. In one study, it was suggested that emotional labor is not suitable for female flight attendants (Hochschilds, 1983), but women in jobs requiring emotional labor are highly satisfied in comparison with men in the same job capacity (Wharton, 1993). Furthermore, females are more adept than men at sensing intuitively the gestures and emotions that are suitable for the workplace (Grandey, 2000). As well, females are more effective at handling emotions while in service work, such that females are more effective at emotional management. This ability increases the positive work experience for them compared to male staff because such emotional management abilities in females are helpful in the capacity of emotional labor.

Overall, then, female store clerks generally enjoy more positive emotions on the job as far as gender socialization is concerned (Rafaeli, 1989). At the same time, greater positivity is expected from women than men because they are more effective in presenting their emotions in a positive way. Consequently, women find it easier to work in adherence to organizational standards, as women are more successful at expressing their emotions authentically (Rafaeli, 1989). The outcome of this is that females have more job satisfaction than men (Bulan, Erickson \& Wharton, 1997). Service work is directly associated with females because they have a nature of caring and use their caring nature in their jobs (Bulan et al., 1997). The requirement for emotional labor coupled with the natural aptitude of women around emotional engagement enables women to adopt deep acting because it is attached to women's emotions and thus will be effective inservice work.

There is a similarity between felt and expressed emotions because deep acting requires naturalness and showing care for customers. Most females have deep acting as part of their behavior, making them better at and more satisfied with their jobs compared to men. On the other hand, as mentioned, surface acting does not present real emotions but features instead expressions that are inauthentic in nature. These inauthentic expressions have a low likelihood of producing good quality services or job satisfaction. Therefore, because the genuine expression of emotions and feelings come more easily to females than males, they are naturally adept at the role of deep acting. This is directly associated with presenting positive emotions and satisfying customers. Females who resort to surface acting have more negative consequences than men in the role of surface acting.

Hypothesis 10: Gender moderates the relationship of surface acting and job satisfaction.

Hypothesis 11: Gender moderates the relationship of deep acting and job satisfaction.

\section{Methodology}

The study closely follows a quantitative research design and empirically tests the above-noted conceptualized relationships. The data were collected using a structured questionnaire. Information related to the measurements, data collection, sampling and data analysis are presented below. 


\section{Measures}

The measurement for the construct presented in the model were used from the existing researcher. Each item was based on a five-point Likert scale. Four items were used to measure job satisfaction (Brown \& Peterson, 1993; Brashear et al., 2003; Hur et al., 2015). In order to measure customer satisfaction, four items were adapted from studies done by Brakus et al. (2003) and Hur et al. (2015). Deep acting was then measured using four items, and surface acting was also measured using four items based on studies published by Diefendorff et al. (2005) and Hur et al. (2015). Based on the results of these measurements, emotional intelligence was measured using five items adapted from studies by Wong and Law (2002) and Johnson and Spector (2007). Note that, for measuring gender, female was coded as " 1 " and male was coded as " 2 ".

\section{Data Collection and Participants}

The study questionnaire comprised two main sections. Section A of the study denotes a variety of demographic information about the respondents, such as their gender, age, income and qualifications of the respondents, while Section B poses questions regarding the constructs included in the conceptual framework, such as the concepts of deep acting, surface acting, job satisfaction, customer satisfaction and emotional intelligence. All of the items were measured using a five-point Likert scale.

The study sample was drawn from a pool of employees working in the banking industry in Libya. For that purpose, 500 bank employees were randomly selected, and questionnaires sent to them. At the initial stages, 252 of the original 500 questionnaires were filled out and returned; however, after the remaining employees were contacted, another 112 questionnaires were collected. In total, then, 364 questionnaires were completed by the bank employees and sent back to us. This response gave us a final sample size for the study of 364 .

\section{Data Analysis}

Analysis of the data was performed using SPSS software. The respondents' demographic profiles are depicted in Table 1. As mentioned, we received a total of 364 completed questionnaires, which we used to perform the data analysis. From Table 1, by looking at the frequency of gender, one can notice that male respondents made up about $56 \%$ of the total, while females made up about $44 \%$. Most of the respondents were between the ages of 31 and 40 years (51.6\%), with the next largest age group of respondents being between the ages of 20 and 30 years (32.4\%). Respondents between the ages of 41 and 50 years were the third-largest group (11\%), and the remaining respondents (4.9\%) were over the age of 50 years. Most of the respondents earned a monthly salary of between $\$ 500$ and $\$ 1000$ (59.3\%), while the next largest group earned a salary below $\$ 500$ (29.7\%), and the remaining (11\%) earned above $\$ 1000$. As for the formal education qualifications of the respondents, most of them (59\%) had earned Bachelor degrees, while then next largest group (29\%) had earned either a Master or PhD degree, and the remaining (12.4\%) held other qualifications. 
Table 1: Demographic Attributes of the Respondents

\begin{tabular}{|c|c|c|c|c|}
\hline NO & & $\begin{array}{l}\text { Respondent's } \\
\text { Profile }\end{array}$ & Frequency & $\begin{array}{c}\text { Percentage } \\
(\%)\end{array}$ \\
\hline \multirow[t]{3}{*}{1} & \multirow{3}{*}{ Gender } & Male & 204 & 56 \\
\hline & & & & \\
\hline & & Female & 160 & 44 \\
\hline \multirow[t]{4}{*}{2} & \multirow{4}{*}{ Age } & $20-30$ & 118 & 32.4 \\
\hline & & $31-40$ & 188 & 51.6 \\
\hline & & $41-50$ & 40 & 11 \\
\hline & & Over 50 & 18 & 4.9 \\
\hline \multirow[t]{3}{*}{3} & \multirow{3}{*}{ Monthly income } & Below $\$ 500$ & 108 & 29.7 \\
\hline & & $\$ 500$ to 1000 & 216 & 59.3 \\
\hline & & More than $\$ 1000$ & 40 & 11 \\
\hline \multirow[t]{3}{*}{4} & \multirow{3}{*}{$\begin{array}{c}\text { Highest Academic } \\
\text { Qualification }\end{array}$} & Bachelor & 214 & 58.8 \\
\hline & & Master / PhD & 105 & 28.8 \\
\hline & & Other & 45 & 12.4 \\
\hline
\end{tabular}

\section{Reliability, Descriptive and Inter-Correlation Analysis}

Reliability and descriptive analyses are presented in Table 2. As can be seen, the mean value for surface acting is 3.06; the mean value for deep acting is 3.02; the mean value for job satisfaction is 3.6; the mean for customer satisfaction is 2.86; and the mean value for emotional intelligence is 3.02. For these values, there is a standard deviation of $0.69,1.09,1.09,1.07$ and 0.89 , respectively. Meanwhile, the skewness for all variables ranged between -0.46 and 0.25 , showing no issue of abnormality. Specifically, the values for Kolmogorov-Smirnov all showed above 0.05, confirming normality.

Next, the scale reliability of the construct was examined using Cronbach's alpha. The ideal threshold for the alpha is 0.7 (Pallant, 2011). The scale reliability test for all constructs showed alpha values greater than 0.7 for all constructs. An inter-item correlation was also performed, and all values were found to be between the range of 0.70 and 0.81 . These correlation values suggest a strong relationship (Briggs \& Cheek, 1986). 
INTERNATIONAL JOURNAL OF ACADEMIC RESEARCH IN BUSINESS AND SOCIAL SCIENCES

Vol. 9, No. 11, November, 2019, E-ISSN: 2222-6990 @ 2019 HRMARS

Table 2: Descriptive Statistics and Reliability Analysis

\begin{tabular}{|c|c|c|c|c|c|c|c|c|}
\hline NO & Variables & $\begin{array}{l}\text { No.of } \\
\text { Items }\end{array}$ & Mean & $\begin{array}{l}\text { Standard } \\
\text { Deviation }\end{array}$ & Skewness & $\begin{array}{l}\text { Kolmogorov } \\
\text {-Smirnov }\end{array}$ & $\begin{array}{l}\text { Inter-Items } \\
\text { Coefficients }\end{array}$ & $\begin{array}{l}\text { Cronbach } \\
\alpha\end{array}$ \\
\hline $\mathbf{1}$ & SUR_ACT & 04 & $\begin{array}{c}3.069 \\
4\end{array}$ & 0.69988 & 0.071 & 0.09 & 0.713 & 0.795 \\
\hline $\mathbf{2}$ & DEEP_ACT & 04 & $\begin{array}{c}3.028 \\
2\end{array}$ & 1.09990 & 0.059 & 0.17 & 0.701 & 0.715 \\
\hline $\mathbf{3}$ & JOB_SAT & 04 & $\begin{array}{c}3.608 \\
5\end{array}$ & 1.09449 & -0.462 & 0.12 & 0.752 & 0.881 \\
\hline $\mathbf{4}$ & CUS_SAT & 04 & $\begin{array}{c}2.865 \\
4\end{array}$ & 1.07184 & 0.252 & 0.14 & 0.818 & 0.901 \\
\hline $\mathbf{5}$ & EM_INT & 05 & $\begin{array}{c}3.022 \\
5\end{array}$ & 0.89998 & 0.111 & 0.11 & 0.771 & 0.870 \\
\hline
\end{tabular}

Table 3: Correlation Matrix

\begin{tabular}{|c|c|c|c|c|c|}
\hline NO & Deep Acting & $\begin{array}{c}\text { Surface } \\
\text { Acting }\end{array}$ & $\begin{array}{c}\text { Job } \\
\text { Satisfaction }\end{array}$ & $\begin{array}{c}\text { Customer } \\
\text { Satisfaction }\end{array}$ \\
\hline 1 & Deep Acting & 1 & & & \\
\hline 2 & Surface Acting & -.007 & 1 & & \\
\hline 3 & Job Satisfaction & $.349^{* *}$ & $-.125^{*}$ & 1 & \\
\hline 4 & Customer Satisfaction & $.380^{* *}$ & $-.280^{* *}$ & $.345^{* *}$ & 1 \\
\hline
\end{tabular}

** Correlation is significant at the 0.01 level (2-tailed).

* Correlation is significant at the 0.05 level (2-tailed).

In order to determine the strength and direction of the linear relationship of dependent and independent variables, a correlation was performed. The results of the correlation are presented in Table 3. The correlation values under 0.20 show a very low correlation. Specifically, values between 0.20 and 0.40 mean that the correlation is low; values between 0.40 and 0.70 mean that the correlation is at a moderate level; values between 0.70 and 0.90 mean that the correlation is considered to be high; and values above 0.90 mean that the correlation is considered to be very high. However, a high correlation between predictors can be prone to multi-collinearity (Winship \& Western, 2016). In the current study, surface acting was significantly correlated with job satisfaction and customer satisfaction. In the same way, deep acting was also found to be significantly correlated with job satisfaction and customer satisfaction, while job satisfaction was found to be correlated with customer satisfaction. However, none of the correlation coefficients of the independent variables were found to be higher. Hence, there is no issue of multi-collinearity. 


\section{Hypotheses Testing}

This section presents the hypotheses testing for the study. First, the direct relationships in the hypotheses are examined ( $\mathrm{H} 1$ to $\mathrm{H} 5)$, after which the mediated relationships are tested ( $\mathrm{H} 6$ and $\mathrm{H7}$ ), followed by testing of the moderated relationships ( $\mathrm{H} 8$ and $\mathrm{H} 9$ ).

The direct relationships of surface acting and job satisfaction, deep acting and job satisfaction, surface acting and customer satisfaction, deep acting and customer satisfaction, and job satisfaction and customer satisfaction were tested and found to be supported. Hence, hypotheses $\mathrm{H} 1$ to $\mathrm{H} 5$ were supported.

Table 4: Results of Hypothesis Testing (Direct Relationships)

\begin{tabular}{|c|l|l|l|l|c|}
\hline NO & \multicolumn{1}{|c|}{ Hypotheses Path } & $\begin{array}{c}\text { Standardized } \\
\text { Path } \\
\text { Coefficients }\end{array}$ & T-value & $\begin{array}{c}\text { P- } \\
\text { value }\end{array}$ & Result \\
\hline 1 & Surface Acting $\rightarrow$ Job Satisfaction & -.122 & -2.50 & $.013^{*}$ & Supported \\
\hline 2 & Deep Acting $\rightarrow$ Job Satisfaction & .348 & 7.11 & $.000^{*}$ & Supported \\
\hline 3 & $\begin{array}{c}\text { Surface Acting } \rightarrow \text { Customer } \\
\text { Satisfaction }\end{array}$ & -.252 & -5.49 & $.000^{*}$ & Supported \\
\hline 4 & $\begin{array}{c}\text { Deep Acting } \rightarrow \text { Customer } \\
\text { Satisfaction }\end{array}$ & .306 & 6.30 & $.000^{*}$ & Supported \\
\hline 5 & $\begin{array}{c}\text { Job Satisfaction } \rightarrow \text { Customer } \\
\text { Satisfaction }\end{array}$ & .207 & 4.23 & $.000^{*}$ & Supported \\
\hline
\end{tabular}

*Statistically significant at the $5 \%$ level ( $p$-value $<0.05)$.

\section{Hypothesis Testing for Mediation Analysis}

In order to test the mediated relationships, a method proposed by Baron and Kenny (1986) was used and the four steps introduced by these researchers were followed to understand the mediated relationships. In the current model, customer satisfaction is affected by surface acting and deep acting through the mediation of job satisfaction. For that purpose, we first ran a regression to test the relationship of dependent and independent variables. From doing this, we found the relationship of surface acting and customer satisfaction to be significant. Moreover, the relationship of deep acting and customer satisfaction was also significant. In the second step, the relationships of independent variables (surface acting and deep acting) and mediating variable (job satisfaction) were tested. Again, the relationship of these variables was found to be significant. Next, the third step according to Baron and Kenny's (1986) four-step method was done, which included using the mediating variable (job satisfaction) as an independent variable, along with deep acting and surface acting in the model. Meanwhile, customer satisfaction was kept as the dependent variable. The results showed that in the presence of the mediating variable (job satisfaction), deep acting and surface acting still has a significant impact on customer satisfaction, thus confirming the third step of the method. 
The fourth step in the mediation testing process presented the results of the previous three steps of mediation testing in order to let us know whether or not the mediation was full or partial. Note that in cases where the independent variables significantly impacted the dependent variable, the presence of the mediator is called partial mediation. From this, we were able to see that the relationship of surface acting and deep acting with customer satisfaction is partially mediated by job satisfaction (for details, see Table 5 below).

Table 5: Summary of Mediation Hypotheses Testing and Results (Baron and Kenny method)

\begin{tabular}{|l|l|l|l|l|}
\hline Hypothesis & \multicolumn{3}{|c|}{ P-Values } & \\
\hline $\begin{array}{l}\text { Surface Acting } \rightarrow \text { Job Satisfaction } \\
\rightarrow \text { Customer Satisfaction }\end{array}$ & SA $\rightarrow$ CS & SA $\rightarrow$ JS & $\begin{array}{l}\text { SA } \rightarrow \text { CS } \\
\text { (including } \\
\text { JS) }\end{array}$ & Result \\
\cline { 2 - 5 } & 0.000 & 0.000 & 0.000 & $\begin{array}{l}\text { Supporting } \\
\text { (Partial } \\
\text { Mediation) }\end{array}$ \\
\hline $\begin{array}{l}\text { Surface Acting } \rightarrow \text { Job Satisfaction } \\
\rightarrow \text { Customer Satisfaction }\end{array}$ & DA $\rightarrow$ CS & DA $\rightarrow$ JS & $\begin{array}{l}\text { DA } \rightarrow \text { CS } \\
\text { (including } \\
\text { JS) }\end{array}$ & Result \\
\cline { 2 - 5 } & 0.000 & 0.000 & 0.000 & $\begin{array}{l}\text { Supporting } \\
\text { (Partial } \\
\text { Mediation) }\end{array}$ \\
\hline
\end{tabular}

Table 5 shows that the hypotheses $\mathrm{H} 6$ and $\mathrm{H} 7$ were found to be supported, as the mediating role of job satisfaction is significant in the relationship of emotional labor and customer satisfaction.

\section{Hypotheses Testing for Moderation Analysis}

In order to test the moderation effect of gender and emotional intelligence, we created the interaction terms and ran them along with the dependent variables and moderators. The impact of the interaction term (surface acting $x$ gender, deep acting $x$ gender, surface acting $x$ emotional intelligence and deep acting $x$ emotional intelligence) on job satisfaction were then tested. The results are presented in Table 6 below. 
Table 6: Results of Hypothesis Testing (Moderated Relationships)

\begin{tabular}{|c|c|c|c|c|c|}
\hline NO & Hypotheses Path & $\begin{array}{c}\text { Standardized } \\
\text { Path } \\
\text { Coefficients }\end{array}$ & T-value & $\begin{array}{l}\mathrm{P}- \\
\text { value }\end{array}$ & Result \\
\hline 1 & $\begin{array}{llll}\text { Surface Acting } & \text { x } & \text { gender } \rightarrow \text { Job } \\
\text { Satisfaction }\end{array}$ & -.108 & -1.199 & .231 & $\begin{array}{c}\text { Not } \\
\text { Supported }\end{array}$ \\
\hline 2 & Deep Acting $\mathbf{x}$ gender $\rightarrow$ Job Satisfaction & .303 & 2.128 & .034 & Supported \\
\hline 3 & $\begin{array}{l}\text { Surface Acting } \quad x \quad \text { El } \rightarrow \text { Customer } \\
\text { Satisfaction }\end{array}$ & .087 & .861 & .390 & $\begin{array}{c}\text { Not } \\
\text { Supported }\end{array}$ \\
\hline 4 & $\begin{array}{l}\text { Deep Acting } \quad x \quad \text { El } \rightarrow \text { Customer } \\
\text { Satisfaction }\end{array}$ & -.710 & -4.651 & .000 & Supported \\
\hline
\end{tabular}

Table 6 above shows that the moderation effect of gender on the relationship of deep acting and job satisfaction is significant. The relationship of deep acting and job satisfaction is also significantly moderated by emotional intelligence, hence supporting hypotheses $\mathrm{H} 9$ and $\mathrm{H} 11$. Meanwhile, the relationship of surface acting and job satisfaction is not moderated by either of the two variables (i.e., gender and emotional intelligence), which means that hypotheses $\mathrm{H} 8$ and $\mathrm{H} 10$ were not supported.

Table 7: Overall Summary of Hypotheses

\begin{tabular}{|c|l|c|}
\hline NO & \multicolumn{1}{|c|}{ Hypotheses } & \multicolumn{1}{|c|}{ Results } \\
\hline 1 & Surface acting is negatively associated with customer satisfaction. & Supported \\
\hline 2 & Deep acting is positively associated with customer satisfaction. & Supported \\
\hline 3 & Surface acting is negatively associated with job satisfaction. & Supported \\
\hline 4 & Deep acting is positively associated with job satisfaction. & Supported \\
\hline 5 & Job satisfaction is positively associated with customer satisfaction. & Supported \\
\hline 6 & $\begin{array}{l}\text { The relationship of surface acting and customer satisfaction is mediated by } \\
\text { job satisfaction. }\end{array}$ & Supported \\
\hline 7 & $\begin{array}{l}\text { The relationship of deep acting and customer satisfaction is mediated by } \\
\text { job satisfaction. }\end{array}$ & Supported \\
\hline 8 & $\begin{array}{l}\text { Emotional intelligence moderates the relationship of surface acting and job } \\
\text { satisfaction }\end{array}$ & Supported \\
\hline 9 & $\begin{array}{l}\text { Emotional intelligence moderates the relationship of deep acting and job } \\
\text { satisfaction }\end{array}$ & Supported \\
\hline 10 & $\begin{array}{l}\text { Gender moderates the relationship of surface acting and job satisfaction } \\
\text { 11 }\end{array}$ & Sender moderates the relationship of deep acting and job satisfaction \\
\hline
\end{tabular}




\section{Discussion}

The present study was proposed to examine the impact of emotional labor on customer satisfaction both directly and with the mediation of job satisfaction. Additionally, the moderation of gender and emotional intelligence was also tested. The study findings make important contributions to the existing body of knowledge in the following ways. Firstly, the results indicate the impact of surface acting and deep acting on customer satisfaction both directly and with the mediation of job satisfaction. These relationships are supported in the literature (e.g., Söderlund and Rosengren, 2008, 2010; Groth et al., 2009; Hatfield et al., 2018). Furthermore, we identified employee job satisfaction as the factor most likely to mediate the link between employee emotional labor and customer satisfaction. Despite the important role of employee job satisfaction over changes in a customer's affective state in service transactions (Hatfield et al., 1994), no previous studies have yet highlighted the role of employee job satisfaction on the relationship between employee emotional labor and customer satisfaction. Our study contributes to the knowledge field by providing an empirical test of how employee job satisfaction mediates the relationship between employee emotional labor and customer satisfaction. Moreover, the study found a moderating effect of gender and emotional intelligence on the relationship of deep acting and job satisfaction, results that are supported by Johnson and Spector's (2007) study.

\section{Conclusion}

The study examined the impact of surface acting and deep acting on customer satisfaction directly and with the mediation of job satisfaction. Moreover, the moderating effect of gender and emotional intelligence was tested on the relationship of emotional labor (surface acting and deep acting) and job satisfaction. As well, the direct relationships of surface acting and job satisfaction, deep acting and job satisfaction, surface acting and customer satisfaction, deep acting and customer satisfaction, and job satisfaction and customer satisfaction were tested and found to be supported. Hence, the hypotheses designated as $\mathrm{H} 1$ to $\mathrm{H} 5$ were supported. Furthermore, hypotheses $\mathrm{H} 6$ and $\mathrm{H} 7$ were also found to be supported, as the mediating role of job satisfaction is significant in the relationship of emotional labor and customer satisfaction. The moderating effect of gender on the relationship of deep acting and job satisfaction is significant. The relationship of deep acting and job satisfaction is also significantly moderated by emotional intelligence, which means it supports hypotheses $\mathrm{H} 9$ and $\mathrm{H} 11$. However, the relationship of surface acting and job satisfaction is not moderated by either of the two variables of gender or emotional intelligence, indicating that hypotheses $\mathrm{H} 8$ and $\mathrm{H} 10$ were not supported.

\section{Limitations and Future Research}

Although our study has several implications for the emotional labor literature, it also has limitations that must be taken into account in future research. First, the study sample is taken solely from banking professionals working in Libya, which can present an issue for the generalization of the research findings across other cultural environments. The implication is that future work should be done across different cultural contexts. Secondly, the study did not bring 
any control variables into the equation, so future research should consider introducing some control variables. Finally, the mediating effect of job satisfaction and the moderated effects of gender and emotional intelligence were also considered in the present study. However, the mediating effects of organizational commitment and emotional exhaustion are recommended for further investigation in future research.

\section{References}

Adelman, M. B., \& Ahuvia, A. C. (1995). Social Support in the Service Sector: The Antecedents, Processes, and Outcomes of Social Support in an Introductory Service. Journal of Business Research, 32(3), 273-282.

Alsakarneh, A. A. A., Hong, S. C., Eneizan, B. M., \& AL-Kharabsheh, K. A. (2019). Exploring the Relationship between the Emotional Labor and Performance in the Jordanian Insurance Industry. Current Psychology, 38(5), 1140-1151.

Alsakarneh, A. A., Chao Hong, S., Eneizan, M., B., \& AL-Kharabsheh, K. A. (2018). Explore The Relationship Between Human Resource Management Practices And The Consequences For Emotional Labor Of Insurance Agents In The Jordanian Insurance Industry. Cogent Business \& Management, 5(1), 1445407.

Arnold, K. A., Connelly, C. E., Walsh, M. M., \& Martin Ginis, K. A. (2015). Leadership Styles, Emotion Regulation, and Burnout. Journal of Occupational Health Psychology, 20(4), 481.

Barsade, S. G., Coutifaris, C. G., \& Pillemer, J. (2018). Emotional Contagion in Organizational Life. Research in Organizational Behavior.

Bartram, T., Casimir, G., Djurkovic, N., Leggat, S. G., \& Stanton, P. (2012). Do Perceived High Performance Work Systems Influence the Relationship between Emotional Labor, Burnout and Intention to Leave? A Study of Australian Nurses. Journal of Advanced Nursing, 68, 7, 1567-1578.

Bhave, D. P., \& Glomb, T. M. (2016). The Role of Occupational Emotional Labor Requirements on the Surface Acting-Job Satisfaction Relationship. Journal of Management, 42(3), 722-741.

Brakus, J. J., Schmitt, B. And Zaratonello, L. (2009), "Brand Experience: What Is It? How Is It Measured? Does It Affect Loyalty?" Journal of Marketing, Vol. 73 No. 3, Pp. 52-68.

Brashear, T. G., White, E. L. And Chelariu, C. (2003), "An Empirical Test of Antecedents and Consequences of Salesperson Job Satisfaction among Polish Retail Salespeople", Journal of Business Research, Vol. 56 No. 12, Pp. 971-978.

Briggs, S. R., \& Cheek, J. M. (1986). The Role of Factor Analysis in the Development and Evaluation of Personality Scales. Journal of Personality, 54(1), 106-148.

Brotheridge, C. M., \& Grandey, A. A. (2002). Emotional Labor and Burnout: Comparing Two Perspectives of "People Work". Journal of Vocational Behavior, 60(1), 17-39.

Brotheridge, C. M., \& Lee, R. T. (2002). Testing a Conservation of Resources Model of the Dynamics of Emotional Labor. Journal of Occupational Health Psychology, 7(1), 57.

Brown, S. P. And Peterson, R. A. (1993), "Antecedents and Consequences of Salesperson Job Satisfaction: Meta-Analysis and Assessment of Causal Effects", Journal of Marketing Research, Vol. 30 No. 1, Pp. 63-77. 
Brown, S. P., \& Lam, S. K. (2008). A Meta-Analysis of Relationships Linking Employee Satisfaction to Customer Responses. Journal of Retailing, 84(3), 243-255.

Bulan, H. F., Erickson, R. J., \& Wharton, A. S. (1997). Doing For Others on the Job: The Affective Requirements of Service Work, Gender, and Emotional Well-Being. Social Problems, 44, 235-256.

Chapman, E., \& Evans, M. (2016). Leading Through Emotional Labor: Child Protection Assessment Officers in High Quality Call-Centre. In 30th Australian and New Zealand Academy of Management Conference: ANZAM 2016 (Pp. 1-13). Australian and New Zealand Academy of Management.

Chapman, E., \& Evans, M. (2016). Leading Through Emotional Labor: Child Protection Assessment Officers in High Quality Call-Centre. In 30th Australian and New Zealand Academy of Management Conference: ANZAM 2016 (Pp. 1-13). Australian and New Zealand Academy of Management.

Chau, S. L., Dahling, J. J., Levy, P. E., \& Diefendorff, J. M. (2009). A Predictive Study of Emotional Labor and Turnover. Journal of Organizational Behavior, 30, 1151- 1163.

Chen, Z., Sun, H., Lam, W., Hu, Q., Huo, Y., \& Zhong, J. A. (2012). Chinese Hotel Employees in the Smiling Masks: Roles of Job Satisfaction, Burnout, and Supervisory Support in Relationships between Emotional Labor and Performance. The International Journal of Human Resource Management, 23(4), 826-845.

Cheung, F., \& Tang, C. (2010). The Influence of Emotional Dissonance on Subjective Health and Job Satisfaction: Testing the Stress-Strain-Outcome Model. Journal of Applied Social Psychology, 40(12), 3192-3217.

Collier, J. E., Barnes, D. C., Abney, A. K., \& Pelletier, M. J. (2018). Idiosyncratic Service Experiences: When Customers Desire The Extraordinary In A Service Encounter. Journal of Business Research, 84, 150-161.

Delcourt, C., Gremler, D. D., Riel, V. A. C., \& Birgelen, V. M. J. (2016). Employee Emotional Competence: Construct Conceptualization and Validation of a Customer-Based Measure. Journal of Service Research, 19(1), 72-87.

Diefendorff, J. M. And Richard, E. M. (2003), "Antecedents and Consequences of Emotional Display Rule Perceptions", Journal of Applied Psychology, Vol. 88 No. 2, Pp. 284-294.

Diefendorff, J. M. And Richard, E. M. (2003), "Antecedents And Consequences Of Emotional Display Rule Perceptions", Journal Of Applied Psychology, Vol. 88 No. 2, Pp. 284-294.

Diefendorff, J. M., Croyle, M. H., \& Gosserand, R. H. (2005). The Dimensionality and Antecedents of Emotional Labor Strategies. Journal of Vocational Behavior, 66(2), 339-357.

Doucet, L. (2004), "Service Provider Hostility and Service Quality", Academy Of Management Journal, Vol. 47 No. 5, Pp. 761-772.

Ejike, S.I. (2018). An Assessment of Non-Executive Directors Influence on the Operating Profits of Manufacturing Firms in Nigeria, International Journal of Academic Research in Accounting, Finance and Management Sciences 8 (2): 1-8.

Festinger, L. (1957). A Theory of Cognitive Dissonance. Stanford, CA: Stanford University Press. 
Gabriel, A. S., Cheshin, A., Moran, C. M., \& Van Kleef, G. A. (2016). Enhancing Emotional Performance and Customer Service through Human Resources Practices: A Systems Perspective. Human Resource Management Review, 26(1), 14-24.

Geofroy, D. Z., \& Evans, M. M. (2017). Are Emotionally Intelligent Employees Less Likely To Hide Their Knowledge? Knowledge and Process Management, 24(2), 81-95.

Goodman, J. (2019). Strategic Customer Service: Managing The Customer Experience To Increase Positive Word Of Mouth, Build Loyalty, And Maximize Profits. Amacom.

Grandey, A. (2003), "When 'The Show Must Go On': Surface And Deep Acting As Predictors Of Emotional Exhaustion And Service Delivery", Academy Of Management Journal, Vol. 46 No. 1, Pp. 86-96.

Grandey, A. A. (2000). Emotion Regulation in the Workplace: A New Way to Conceptualize Emotional Labor. Journal of Occupational Health Psychology, 5, 95-110.

Groth, M., Hennig-Thurau, T. And Walsh, G. (2009), "Customer Reactions to Emotional Labor: The Roles of Employee Acting Strategies and Customer Detection Accuracy", Academy Of Management Journal, Vol. 52 No. 5, Pp. 958-974.

Groth, M., Hennig-Thurau, T. And Walsh, G. (2009), "Customer Reactions to Emotional Labor: The Roles of Employee Acting Strategies and Customer Detection Accuracy", Academy Of Management Journal, Vol. 52 No. 5, Pp. 958-974.

Groth, M., Hennig-Thurau, T. And Walsh, G. (2009), "Customer Reactions to Emotional Labor: The Roles of Employee Acting Strategies and Customer Detection Accuracy", Academy Of Management Journal, Vol. 52 No. 5, Pp. 958-974.

Guy, M. E. (2011). State Power, Citizen Rapport, and Civil Society. 한국행정학회 학술발표논문집, 1014-1031.

Hatfield, E., Cacioppo, J. T., and Rapson, R. L. (1994), Emotional Contagion, Cambridge University Press,

Hatfield, E., Rapson, R. L., \& Narine, V. (2018). Emotional Contagion in Organizations: CrossCultural Perspectives. In Individual, Relational, And Contextual Dynamics of Emotions (Pp. 245-258). Emerald Publishing Limited.

Hennig-Thurau, T., Groth, M., Paul, M., And Gremler, D. D. (2006), “Are All Smiles Created Qual? How Emotional Contagion And Emotional Labor Affect Service Relationships", Journal Of Marketing, Vol. 70 No. 3, Pp. 58-73.

Hennig-Thurau, T., Groth, M., Paul, M., And Gremler, D. D. (2006), “Are All Smiles Created Equal? How Emotional Contagion And Emotional Labor Affect Service Relationships", Journal Of Marketing, Vol. 70 No. 3, Pp. 58-73.

Hochschild, A. R. (1983). The Managed Heart: Commercialization of Human Feeling. Berkeley, CA: University Of California Press.

Hogreve, J., Iseke, A., Derfuss, K., \& Eller, T. (2017). The Service-Profit Chain: A Meta-Analytic Test of a Comprehensive Theoretical Framework. Journal of Marketing, 81(3), 41-61. 
Hu, H. H. S., Hu, H. Y., \& King, B. (2017). Impacts of Misbehaving Air Passengers on Frontline Employees: Role Stress and Emotional Labor. International Journal of Contemporary Hospitality Management, 29(7), 1793-1813.

Humphrey, R. H., Ashforth, B. E., \& Diefendorff, J. M. (2015). The Bright Side of Emotional Labor. Journal of Organizational Behavior, 36(6), 749-769.

Hur, W. M., Moon, T. W., \& Jung, Y. S. (2015). Customer Response to Employee Emotional Labor: The Structural Relationship between Emotional Labor, Job Satisfaction, and Customer Satisfaction. Journal of Services Marketing, 29(1), 71-80.

Johnson, H. A. M., \& Spector, P. E. (2007). Service With A Smile: Do Emotional Intelligence, Gender, And Autonomy Moderate The Emotional Labor Process? Journal of Occupational Health Psychology, 12(4), 319.

Johnson, H. A. M., \& Spector, P. E. (2007). Service With A Smile: Do Emotional Intelligence, Gender, And Autonomy Moderate The Emotional Labor Process? Journal of Occupational Health Psychology, 12(4), 319.

Jordan, P. J., \& Troth, A. (2011). Emotional Intelligence and Leader Member Exchange: The Relationship with Employee Turnover Intentions and Job Satisfaction. Leadership \& Organization Development Journal, 32(3), 260-280.

Jung, H. S., \& Yoon, H. H. (2015). The Impact of Employees' Positive Psychological Capital on Job Satisfaction and Organizational Citizenship Behaviors in the Hotel. International Journal of Contemporary Hospitality Management, 27(6), 1135-1156.

Kundu, S., \& Datta, S. K. (2015). "Impact of Trust on the Relationship of E-Service Quality and Customer Satisfaction". Euromed Journal of Business, 10(1), 21-46.

Laban, O. M., \& Deya, J. (2019). Strategic Innovations and the Performance of Information Communication Technology Firms in Nairobi Kenya. International Journal of Academic Research in Progressive Education and Development, 8(2), 1-24.

Lee, J. J., \& Ok, C. (2012). Reducing Burnout and Enhancing Job Satisfaction: Critical Role of Hotel Employees' Emotional Intelligence and Emotional Labor. International Journal of Hospitality Management, 31(4), 1101-1112.

Lee, Y. H., \& Chelladurai, P. (2018). Emotional Intelligence, Emotional Labor, Coach Burnout, Job Satisfaction, and Turnover Intention in Sport Leadership. European Sport Management Quarterly, 18(4), 393-412.

Lv, Q, Xu, S. \& Ji, H. (2012). Emotional Labor Strategies, Emotional Exhaustion, and Turnover Intention: An Empirical Study of Chinese Hotel Employees. Journal of Human Resources in Hospitality \& Tourism, 11, 87-105.

Mohamad, M., \& Jais, J. (2016). Emotional Intelligence and Job Performance: A Study among Malaysian Teachers. Procedia Economics and Finance, 35, 674-682.

Nixon, E. A., Yang, L., Spector, P. E. \& Zhang, X. (2010). Emotional Labor In China: Do Perceived Organization Support And Gender Moderate The Process. Stress and Health, 27, 289-305.

Pallant, J. (2011). Survival Manual. A Step By Step Guide to Data Analysis Using SPSS.

Pines, A. M. (2017). Burnout: An Existential Perspective. In Professional Burnout (Pp. 33-51). Routledge. 
Rafaeli, A. (1989). When Clerks Meet Customers: A Test Of Variables Related To Emotional Expression On The Job. Journal of Applied Psychology, 74, 385-393.

Sharma, P., Kong, T. T. C., \& Kingshott, R. P. (2016). Internal Service Quality as a Driver of Employee Satisfaction, Commitment and Performance: Exploring the Focal Role of Employee Well-Being. Journal of Service Management, 27(5), 773-797.

Söderlund, M., \& Rosengren, S. (2008). Revisiting the Smiling Service Worker and Customer Satisfaction. International Journal of Service Industry Management, 19(5), 552-574.

Sony, M., \& Mekoth, N. (2016). The Relationship between Emotional Intelligence, Frontline Employee Adaptability, Job Satisfaction and Job Performance. Journal of Retailing and Consumer Services, 30, 20-32.

Tepeci, M., \& Pala, T. (2016). The Effects of Job-Focused and Employee-Focused Emotional Labor on Burnout in the Hospitality Industry in Turkey. Journal of Global Strategic Management, 10(2), 95-105.

Wharton, A. S. (1993). The Affective Consequences of Service Work. Work and Occupations, 20, 205-232.

Winship, C., \& Western, B. (2016). Multicollinearity and Model Misspecification. Sociological Science, 3(27), 627-649.

Wong, C. S., \& Law, K. S. (2002). Development of an Emotional Intelligence Instrument and an Investigation of Its Relationship with Leader and Follower Performance and Attitudes. The Leadership Quarterly, 13: 243-274.

Wong, C. S., \& Law, K. S. (2002). The Effects of Leader and Follower Emotional Intelligence on Performance and Attitude: An Exploratory Study. The Leadership Quarterly, 13(3), 243274.

Zablah, A. R., Carlson, B. D., Donavan, D. T., Maxham III, J. G., \& Brown, T. J. (2016). A CrossLagged Test of the Association between Customer Satisfaction and Employee Job Satisfaction in a Relational Context. Journal of Applied Psychology, 101(5), 743. 